\title{
O CONTRIBUTO DOS JORNALISTAS PORTUGUESES PARA A REVISTA INFORMAÇÃO, CULTURA POPULAR E TURISMO (1970-1973), DO GABINETE TÉCNICO DA SECRETARIA DE ESTADO DA INFORMAÇÃO E TURISMO
}

\author{
THE CONTRIBUTION OF THE PORTUGUESE JOURNALISTS TO THE \\ PUBLICATION INFORMAÇÃO, CULTURA POPULAR E TURISMO (1970-1973), \\ OF GABINETE TÉCNICO DA SECRETARIA DE ESTADO DA INFORMAÇÃO \\ E TURISMO
}

\author{
Patrícia Oliveira Teixeira*
}

\begin{abstract}
RESUMO
Por que é que a revista Informação, Cultura Popular e Turismo, editada entre 1970 e 1973 pelo Gabinete Técnico da Secretaria de Estado da Informação e Turismo, um organismo governamental, deu atenção ao jornalismo, isto é, à Informação? Talvez porque, ao tempo, o jornalismo atravessava um processo de transformação e modernização que acentuava a sua relevância social e, como tal, era motivo de reflexão. Este trabalho teve, assim, por objetivo descrever, através de uma análise qualitativa do discurso, os conteúdos sobre jornalismo, publicados por jornalistas em Informação, Cultura Popular e Turismo, determinando: (1) quais os assuntos abordados pelos jornalistas que colaboraram nessa publicação, quando em questão estava o jornalismo; e (2) quais os enquadramentos simbólicos construídos discursivamente. Concluiu-se que os jornalistas que escreveram nas páginas de Informação, Cultura Popular e Turismo as suas reflexões acerca do jornalismo contribuíram para a construção do Pensamento Jornalístico Português.
\end{abstract}

Palavras-chave: Informação. Cultura popular e turismo. Jornalismo. Portugalséculo XX.

\begin{abstract}
Why is it that the magazine Informação, Cultura Popular e Turismo, published between 1970 and 1973 by the Secretariat of State for Information and Culture, a government organism, gave attention to journalism, that is, to information? Perhaps because, at that time, journalism was experiencing a process of transformation and modernization that emphasized its social relevance and, as such, was the cause for reflection. This work aims to describe through a qualitative discourse analysis, the content about journalism, published by journalists of the Informação, Cultura
\end{abstract}

\footnotetext{
* Doutoranda em Ciência da Informação pela Universidade Fernando Pessoa (UFP/Portugal), mestre em Ciëncias da Comunicação e graduada em Línguas e Literaturas Modernas pela mesma instituição. Email: <tichasd@hotmail.com>
} 
Popular e Turismo, determining: (1) what issues were raised by the journalists who collaborated to this publication, when journalism was on the agenda; and (2) what symbolic frameworks were constructed discursively. It was concluded that the journalists who have written for this magazine and their thoughts about journalism have contributed to the construction of the Journalistic Portuguese Thinking.

Keywords: Information. Popular culture and tourism. Journalism. Portugual-20th Century.

\section{Introdução}

Nos anos setenta do século XX, ainda antes do eclodir da Revolução de Abril de 1974, que viria a pôr fim ao regime do Estado Novo (1933-1974) e já com Marcelo Caetano no poder ${ }^{1}$, o panorama jornalístico português sofreu várias modificações. (CABRERA, 2006, 2010; FRANCO, 1993; SOBREIRA, 2003, 2010; SOUSA, 2008, 2010) Essas modificações levaram a que se discutisse o papel da Informação na sociedade e a importância do jornalismo nos tempos que corriam.

Este trabalho pretende, através de uma análise qualitativa do discurso, apresentar os conteúdos sobre jornalismo, escritos por jornalistas e publicados em Informação, Cultura Popular e Turismo, publicação da entidade governamental Gabinete Técnico da Secretaria de Estado da Informação e Turismo. Ou seja, pretende apurar-se do que fala e como fala a publicação Informação, Cultura Popular e Turismo, quando o jornalismo é o tema e quando os jornalistas são os escritores. O trabalho organizar-se-á em duas partes, sendo que, na primeira, se irá fazer uma breve contextualização histórica, no que diz respeito à situação do país, bem como uma exposição sobre a conjuntura jornalística da época; na segunda, apresentar-se-á a revista em estudo e proceder-se-á à análise dos textos sobre jornalismo da mesma.

A hipótese a testar é a de que em Informação, Cultura Popular e Turismo os jornalistas reflectiram sobre o jornalismo, contribuindo, assim, para a teorização nacional do jornalismo, tendo, em particular, abordado alguns dos temas estruturantes do Pensamento Jornalístico Português anterior a 1974.

Aapuração de dados qualitativos sobre o discurso de Informação, Cultura Popular e Turismo, conforme propõe Sousa (2006, p. 343-376), restringiu-se à inventariação, anotação e descrição dos principais

\footnotetext{
${ }^{1}$ Ocupava o cargo deixado vago por Salazar, de presidente do Conselho de Ministros, equivalente ao cargo de Primeiro-Ministro.
}

enquadramentos discursivamente sugeridos para os jornalistas que falaram sobre o jornalismo.

Concluiu-se que os jornalistas que contribuíram para a revista Informação, Cultura Popular e Turismo, através das suas reflexões acerca do jornalismo, colaboraram para a construção do Pensamento Jornalístico Portugal, anterior a 1974, ao reflectir, nomeadamente, sobre a conjuntura jornalística e vida profissional dos jornalistas; sobre a história do jornalismo; e sobre a teoria do jornalismo em geral.

\section{O período marcelista}

As modificações no panorama jornalístico do final da década de setenta do século XX ocorreram, simultaneamente, com outras transformações no campo da sociedade e da economia, que, no entanto, não contemplaram grandes mudanças no campo político. Rosas (1994, p. 546) explica que, quando emergiu, o marcelismo fê-lo "não como um disfarce demagógico do salazarismo, uma tentativa de o velho regime mascarar a sua continuidade essencial", mas como "o triunfo político de uma corrente reformista” que vinha a manifestar-se já desde décadas anteriores. Ramos et al. (2009, p. 698) contam que Caetano, no seu primeiro discurso, realçou que desejava um regime em que todos os portugueses se sentissem encaixados, mas destacou, também, que esse regime teria de manter (ou continuar a manter) a ordem pública. O então presidente do Conselho de Ministros anunciou, ainda, vários projectos de modernização. Porém, a proclamada "Primavera marcelista" acabara por não florir na tão desejada democracia e tornara-se evidente que se tratara apenas de uma operação de cosmética de um regime que teimava em perpetuar-se. No entanto, algumas mudanças foram operadas, por muito superficiais que possam ter parecido e por muito pouco que tenham vindo alterar os imperturbados conteúdos das instituições. Este 
facto foi particularmente evidente no que se refere a instituições de carácter repressivo ou propagandístico, como o Secretariado Nacional da Informação e Cultura Popular, que passa a designar-se Secretaria de Estado da Informação e Turismo, e a PIDE (Polícia Internacional e de Defesa do Estado), que passa a chamar-se DGS (Direcção-Geral de Segurança). De qualquer modo, à PIDE foram retirados alguns dos seus plenos poderes, a sua actuação foi moderada e a arbitrariedade que a acompanhava desde a sua formação foi diminuída. A Censura também muda de nome para Comissão de Exame Prévio.

O aparelho de Estado também continuou praticamente inalterado, embora se tenham efectuado alguns esforços para modificá-lo. No início de 1970, Marcelo Caetano procede a uma remodelação ministerial, nomeando novos ministros, como, por exemplo, Veiga Simão para a Educação. Esse ministro vai dar início a um amplo programa de reforma do ensino, com a criação de novas universidades (Minho, Aveiro, Nova de Lisboa e Évora), seis institutos politécnicos e oito escolas normais superiores. No entanto, o clima nas universidades portuguesas não era o melhor. Os jovens tinham mais possibilidades de acesso ao ensino superior, porém não queriam aceitar as normas escolares e o policiamento das universidades. O governo havia decretado um "estado de excepção" dentro dessas instituições de ensino, impondo a presença de forças policiais e facilitando as prisões e os processos disciplinares de alunos das mesmas. As associações estudantis, por exemplo, foram quase todas encerradas. Apesar dessa repressão, os protestos estudantis intensificavam-se a cada dia que passava, o que também contribuiu para que o regime suspendesse qualquer política de abertura que pudesse estar em curso e a endurecer a censura.

Entretanto, mercê da conjuntura internacional e das despesas crescentes com a guerra no ultramar (que continuava), a nação portuguesa começou a sentir os efeitos da inflação, que atingiu os $30 \%$, e da subida do preço dos combustíveis, resultante da crise petrolífera de 1973. Essa situação também era motivo de protesto, por parte da população, tendo como consequência, uma vez mais, a não moderação (ou mesmo o fim) das medidas de repressão. Apesar dessa conjuntura, a verdade é que, no começo da década de setenta, com a economia liberalizada, o crescimento do produto interno bruto atingiu va- lores acima da média. As transacções económicas faziam-se, agora, sobretudo a nível europeu. O Governo marcelista pôde, inclusivamente, desenvolver os primeiros mecanismos relevantes de um estado social de matriz europeia. Ocorreu um arejamento das mentalidades, provocado por factores como os progressos na educação, a urbanização, o turismo estrangeiro, a intervenção cultural da Fundação Calouste Gulbenkian e a politização de vários sectores da sociedade portuguesa. Muitos hábitos mudaram, sinal dos novos tempos.

A ligação ao continente europeu reforçou-se pelo fluxo migratório, que prosseguiu em grandes quantidades, tendo por alvo principal a França. A emigração e a guerra contribuíram para fazer baixar o desemprego e as remessas de dinheiro dos emigrantes ajudava a economia a crescer. O que também contribuiu para esse crescimento foi a instalação de empresas estrangeiras em Portugal, atraídas pelos baixos salários. Essas empresas introduziram no país regras e rotinas de trabalho contemporâneas. No entanto, os trabalhadores da metrópole não se sentiam satisfeitos com as suas condições de trabalho, com os salários (que eram “consumidos” pela inflação) e com a falta de liberdade sindical. Nessa altura, contudo, as condições de vida das populações melhoraram substancialmente e já eram em número considerável os alojamentos com electricidade, água canalizada e esgotos.

O início dos anos setenta foi, também, marcado por greves, reivindicações e/ou manifestações de rua. Greves dos estudantes, no sector ferroviário, no sector metalúrgico, no sector têxtil, na banca, etc., que, no entanto, não foram capazes de derrubar o governo, mas fizeram mossa. Sentia-se que havia um espartilho que sufocava a sociedade portuguesa e que podia romper-se a cada momento.

Na realidade, a actuação de Marcelo Caetano até se iniciou sob o signo da evolução, retomando o essencial do seu projecto de modernização política, económica, social e até colonial. Mas o peso do regime cedo inflectiu o curso da política a prosseguir, que, nomeadamente no que refere à informação, se situará predominantemente na área da continuidade. (FRANCO, 1993, p. 143). 


\section{A comunicação e o jornalismo durante o período marcelista}

Sousa (2010, p. 369-372) disseca muito bem as influências do período marcelista na comunicação e no jornalismo, nos primeiros anos da década de setenta. Lendo o livro do autor, conclui-se que o próprio Marcelo Caetano, compreendendo a crescente politização da sociedade portuguesa, não só reflectiu sobre a influência da comunicação social na sociedade, como também propiciou ao seu Governo uma atitude comunicacional pró-activa. Além disso, o Governo marcelista também mobilizou os jornalistas para os mais variados eventos e conferências de imprensa, o que fez recrudescer o interesse pelo jornalismo político. A eleição de parlamentares da Ala Liberal para a Assembleia Nacional, em 1969, também contribuiu para intensificar o reencontro do jornalismo português com a política, perdido após o colapso da I República. Mais próximos dos jornalistas e adeptos da democratização do regime e da liberdade de imprensa, os deputados da Ala Liberal - entre os quais Sá Carneiro e Pinto Balsemão - obtiveram visibilidade para as suas propostas graças à comunicação social.

No entanto, após 1971, com o fim da Primavera Marcelista, procedeu-se a uma tentativa de reforço do controle sobre a comunicação social e a sociedade, exercida pelo Governo de Marcelo Caetano. Porém, a profusão de meios de comunicação social tornou difícil a acção dos serviços de "Exame Prévio". $\mathrm{Na}$ imprensa escrita, e também na rádio, projectos jornalísticos diferenciados, com linhas editoriais politicamente matizadas, eram oferecidos aos públicos, que certamente escolhiam aqueles com os quais mais se identificavam.

No seu segmento, jornais como o Diário Popular, o Diário de Lisboa e o Diário Ilustrado, e revistas como O Século Ilustrado, a Flama e a Vida Mundial renovaram o panorama da imprensa. O Expresso, surgido em 1973, pela mão de Pinto Balsemão, será, possivelmente, um excelente exemplo do dinamismo empresarial no campo do jornalismo impresso e da aparição de novos títulos no final do Estado Novo. Outros jornais, porém, ficaram pelo caminho, porque, embora dificultada, a censura não deixava de agir. O semanário Actividades Económicas, fundado em 1973 para competir com o Expres- so, foi sucessivamente boicotado pela censura, o que não é de admirar, dados os temas que procurou tratar (o primeiro número, por exemplo, seria sobre a carestia de vida e logo na primeira página a manchete era "Vida Cara"). Assim, apesar de ter a redacção em plena laboração e de ter lançado uma campanha de publicidade para anunciar a sua saída, o jornal acabou por ser encerrado. Foi um exemplo concreto de como a censura emperrava o dinamismo da sociedade civil e do jornalismo e prejudicava a própria economia.

Ao nível da profissionalização da actividade jornalística, também se verificaram extraordinários progressos. Essa actividade, na quase totalidade, abandonou a sua característica de "ocupação" ou "ofício” para ir assumindo a condição de profissão liberal (CORREIA; BAPTISTA, 2007, 2010; SOBREIRA, 2003). Essa emergência do profissionalismo jornalístico em Portugal vai incrementar a autonomia de tal campo profissional, alicerçando-a em valores comuns, regras e deveres, mas também na pugna por direitos, incluindo, obviamente, o direito à liberdade de pensamento e de expressão desse pensamento através da imprensa. Assim, no estertor do Estado Novo, os “novos” valores profissionais dos jornalistas portugueses geraram uma tensão permanente entre estes e as autoridades da ditadura.

Tal como dão conta os factos históricos conhecidos e investigações como as de Correia e Baptista (2007; 2010), baseadas em entrevistas com jornalistas portugueses que exerceram a sua actividade nos anos sessenta e início dos setenta, ou a de Sobreira (2003), ancorada, principalmente, em fontes documentais, conclui-se que, nesse período temporal, diminuiu a atitude servil dos jornalistas em relação aos políticos do Estado Novo (alguns jornalistas posicionavam-se, ideologicamente, contra o regime, mesmo no seio do seu sindicato). O Sindicato Nacional dos Jornalistas assumiu um protagonismo inaudito, lutou-se pela liberdade de imprensa e pela instituição de cursos superiores de Jornalismo, desafiaram-se os condicionalismos económicos com imaginação e diminuiu o carácter improvisado e “desenrascado” da actuação dos jornalistas, em favor de uma atitude mais técnica e rotinizada, mais "profissional”, mais ajustada ao ambiente de mudança que se fazia sentir, inclusive no que respeita à introdução de novas tecnologias. 
As principais mudanças que se verificaram na época foram o aumento do número de jornalistas, uma descida da média de idades dos mesmos, um aumento das habilitações literárias desses profissionais e um crescimento do género feminino nas redacções. ${ }^{2}$ Diz Cabrera (2010, p.74), procurando explicar essas modificações, que a alteração no Governo, em 1968, associada à política e estratégia de informação marcelista, criou, no público, uma expectativa que se consubstanciou na necessidade de uma maior informação por parte dos jornais.

Segundo Roseira (2003, p. 28 e 31), em 1970 havia cerca de 500 jornalistas profissionais e 1274 publicações, sendo que destas, 33 eram publicações diárias; 212 semanários, bissemanários e trissemanários; e 989 publicações de outro tipo. Cabrera (2010, p. 74) acrescenta que, entre 1968 e 1974, o número de jornalistas cresceu de forma acentuada, apresentando um aumento de 51,6\%, sendo que as principais razões para esse crescimento foram o aumento do número de publicações e de agências de informação; a alteração nos quadros legais que conferiam estatuto de jornalista a novas publicações; e a oferta de maior número de páginas por jornais e maior diversidade de suplementos, em resultado da cobertura de mais assuntos e temas que habitualmente não faziam parte de agenda noticiosa no período anterior a 1968.

Em relação à média de idades, Cabrera (2010, p. 74-75) explica que a diminuição verificada se relacionou directamente com um aumento na demanda de mão-de-obra e com a admissão de estagiários. A autora acrescenta que, entre 1960 e 1974, a maioria dos jornais viu a sua média de idade descer dez anos e que, enquanto a média de idades dos redactores se situava entre os 40 e os 50 anos e a dos repórteres entre os 30 e os 40, os estagiários situavam-se, normalmente, numa média de 20 anos (CABRERA, 2010, p. 74-75).

Relativamente à mencionada feminização das redacções, Cabrera (2010, p. 75-76) indica que é no princípio da década de setenta que essa situação se altera progressivamente, sendo a partir de 1972 que se dá um crescimento contínuo do género feminino

\footnotetext{
2 De acordo com Cabrera (2010, p. 74) é esse aumento do número de jornalistas que tem efeitos na descida na média de idades, no aumento das habilitações literárias, na quantidade de mulheres que acedem à profissão e no desenvolvimento de atitudes reivindicativas e participação sindical da classe.
}

nas redacções. Resume a autora que estando ainda longe “de situações de paridade numérica foi (...) no princípio dos anos 70, que se iniciou o processo de entrada de mulheres nas redacções sem restrições, associadas à igualdade na distribuição de trabalho entre homens e mulheres, já que em matéria salarial não havia distinções.” (CABRERA, 2010, p. 77). No entanto, a entrada de mulheres nas redacções foi um processo lento, uma vez que elas foram, durante muito tempo, "arredadas da actividade jornalística propriamente dita” (CABRERA, 2010, p. 76), pelas mais variadas razões. Essa aceitação das mulheres nos jornais e a generalização da sua actividade no trabalho de redacção (com uma distribuição de trabalho igual ao do homem) ocorreram, de acordo com Cabrera (2010, p. 77), numa conjuntura de aumento de procura mais qualificada e de uma oferta ainda restrita.

O aumento das habilitações literárias dos jornalistas observa-se, conforme nos conta Cabrera (2010, p. 78), a partir de 1966, altura em que entrou em vigor o Contrato Colectivo de Trabalho, no qual estava estipulado que para o exercício da profissão de jornalista era indispensável possuir o $2{ }^{\circ}$ Ciclo dos Liceus ou equivalente. Já o Contrato Colectivo de Trabalho de 1971 exige como habilitação mínima o 3. ${ }^{\circ}$ Ciclo dos Liceus (mas só para novas admissões) ${ }^{3}$. Refere Cabrera (2010, p. 78) que, a partir dessa data, a direcção do Sindicato Nacional dos Jornalistas teve de mostrar um maior rigor na observação da declaração da habilitação literária por parte dos seus associados.

Ao mesmo tempo em que se assistia a todas essas modificações no jornalismo, a classe jornalística procurava, também, pôr um fim à censura, defendendo a liberdade de expressão e de pensamento. A subida de Marcelo Caetano ao poder criou expectativas na sociedade portuguesa e o meio jornalístico não pôde deixar de aproveitar a oportunidade de colocar na ordem do dia essas questões. (CABRERA, 2010, p. 79-80).

Por seu lado, Franco (1993, p. 6) afirma que, na década de setenta, os deputados da ala liberal já reivindicavam, por oposição ao exame prévio, a liberdade de imprensa e procuravam salvaguardar o princípio da aplicação da lei civil aos jornalistas

\footnotetext{
${ }^{3}$ Admitiam-se algumas excepções. (CABRERA, 2010, p. 78).
} 
como a forma mais eficaz de prever e impedir abusos na liberdade de informação. No entanto, a mensagem não pegou e tanto a censura à imprensa como a repressão sobre os que procuraram desafiar o regime com palavras se mantiveram até 25 de Abril de 1974.

Sousa (2008, p. 111) menciona que as dificuldades para o jornalismo, durante o Estado Novo, não se limitaram à censura e a medidas repressivas (como, por exemplo, a suspensão da publicação por um determinado período de tempo, apreensão de exemplares, multas e mesmo a prisão para jornalistas, editores e vendedores). O autor explica que, por vezes, “os órgãos jornalísticos viam-se, também, impedidos de enviar jornalistas ao exterior para cobrir determinados acontecimentos, nomeadamente quando em causa poderiam estar as posições oficiais do regime [...].” (SOUSA, 2008, p. 111).

No que ao ensino do jornalismo diz respeito, em 1971 começou a funcionar a Escola Superior de Meios de Comunicação Social, estabelecimento de ensino privado lançado pelo Instituto Superior de Línguas e Administração (primeira instituição portuguesa de ensino superior privado, fundada em 1962), um curso de Jornalismo com três anos de duração, extinto após a Revolução de 1974. Um sinal de que, em Portugal, se começava a ver com outros olhos o Jornalismo, cada vez mais perto da sua plena aceitação universitária. Porém, a nível superior, ainda nada havia de concreto e a necessidade cada vez mais urgente de os jornalistas se qualificarem levava a que outras soluções fossem encontradas.

\section{A revista Informação, Cultura Popular e Turismo do Gabinete Técnico da Secretaria de Estado da Informação e Turismo}

Informação, Cultura Popular e Turismo é a primeira revista portuguesa que, no âmbito da comunicação, se pode considerar como tendo intenções "científicas"; ou, pelo menos, a primeira, em Portugal, onde se publicaram artigos científicos sobre comunicação. A sua publicação foi da responsabilidade da Secretaria de Estado da Informação e Turismo, mais precisamente do Gabinete Técnico desse organismo.

A Secretaria de Estado da Informação e Turismo nasceu em finais de 1968 para substituir o extinto Secretariado Nacional da Informação, Cultura
Popular e Turismo. Cabia-lhe superintender nos serviços e actividades relativos à informação, ao turismo e à radiodifusão sonora e visual, teatro, cinema e outros espectáculos e formas de cultura popular. ${ }^{4}$ O Gabinete Técnico constituía um serviço de apoio directo do Secretário de Estado, sob a sua imediata superintendência, incumbindo-lhe, designadamente, emitir pareceres, sugerir providências para o aperfeiçoamento dos serviços, acompanhar a execução de planos, empreendimentos ou determinações, coordenar actividades e inspeccionar serviços, reunir e preparar documentação e elementos estatísticos e exercer quaisquer outras funções convenientes ao perfeito desempenho das atribuições da Secretaria de Estado. ${ }^{5}$

César Moreira Baptista foi Secretário de Estado desse organismo, de 16 de Outubro de 1968 até 7 de Novembro de 1973, quando foi substituído por Pedro Pinto. Ao longo desse período, Moreira Baptista manteve uma enorme coerência na orientação que imprimiu ao seu trabalho, procurando, de forma sistemática, transformar o organismo num órgão essencialmente virado, entre outras coisas, para a produção e controle da informação veiculada pela comunicação social.

Moreira Baptista atribuiu muita importância à comunicação social e à censura. Uma das suas primeiras tarefas foi afastar os militares que desde a Ditadura Militar continuavam a dominar as áreas da censura da imprensa e da inspecção dos espectáculos. Mas a mais importante foi, sem dúvida, a de tentar criar um corpo de especialistas em comunicação de massas e turismo, promovendo para o efeito estudos e lançando uma publicação regular nesse domínio, a revista Informação, Cultura Popular e Turismo. Numa altura em que o jornalismo atravessava tantas mudanças, mas em que ainda não proporcionava aos seus profissionais, por exemplo, um curso superior, essa publicação oferecia a eles a possibilidade de publicarem artigos já com uma certa cientificidade.

Dessa revista saíram dezesseis números, entre 1970 e 1973. O redactor principal da revista foi, ao

\footnotetext{
${ }^{4}$ Diário do Governo, I série, número 269, 15 de Novembro de 1968 Capítulo I, Art. $1 .^{\circ}$

Fonte:<http://dre.pt/pdf1sdip/1968/11/26900/16751681.pdf>

${ }^{5}$ Diário do Governo, I série, número 269, 15 de Novembro de 1968. Capítulo I, Secção II, Art. 5. ${ }^{\circ}$.

Fonte: <http://dre.pt/pdf1sdip/1968/11/26900/16751681.pdf>
} 
longo de toda a sua edição, Luís Filipe de Oliveira e Castro, surgindo o Gabinete Técnico da Secretaria de Estado da Informação e Turismo como director/ editor da publicação. No entanto, apesar de manter um redactor principal, a revista contou com a colaboração de vários outros, vindos das diferentes áreas sobre as quais a publicação se debruçava, sendo a grande maioria deles português, mas apresentando, também, um ou outro estrangeiro (procurando mostrar, dessa forma, o que acontecia de diferente nos outros países relativamente ao assunto em debate). Muitos destes redactores ocupavam cargos de Estado, sendo um deles o próprio Presidente do Conselho de Ministros, Marcelo Caetano. Como já se fez referência, alguns dos redactores da revista eram jornalistas. Nesse campo, temos nomes como os de Dutra Faria, Correia Marques, José Lechner ou José Marques de Melo, e são os seus textos que constituirão o objecto de estudo deste trabalho.

A revista começou, então, a ser publicada em 1970 e terminou a publicação em 1973, tendo uma periodicidade trimestral, periodicidade essa que se manteve ao longo de todo o tempo de publicação, com quatro revistas em cada um dos anos. O número de páginas de cada número variou entre 164 e 354. Nessa revista, de formato A5, foram publicados ensaios, estudos, notas, comentários e antologias sobre assuntos ligados à imprensa, à informação, à publicidade, à cultura popular e ao turismo. Ao longo dos quatro anos de publicações, nos 16 números, foram publicados 158 artigos (54, em 1970; 42, em 1971; 35, em 1972; 27, em 1973). Desses 158 artigos, cinquenta deles versavam sobre assuntos relacionados com a comunicação. Dos cinquenta artigos escritos sobre o mundo da comunicação, 32 deles debruçavam-se especificamente sobre o jornalismo.

\section{Informação, Cultura Popular a Turismo - Os artigos sobre jornalismo}

Os diversos artigos sobre jornalismo publicados em Informação, Cultura Popular e Turismo permitem antever que, mesmo tratando-se de uma revista lançada por um organismo governamental, nela parecem ser abordados os temas que Sousa et al. (2010) afirmam terem sido os mais relevantes da teorização portuguesa do jornalismo anterior a 1974 e os temas que mais preocuparam os jornalistas portugueses durante o Estado Novo: a história do jornalismo, os caminhos que a Informação trilhava, o crescimento dos diversos meios de comunicação de massas, a formação da opinião pública, a importância da comunicação e da Informação na sociedade, a imprensa periódica e não-periódica. Enfim, os temas que estruturaram aquele que, de acordo com Sousa et al. (2010), foi o Pensamento Jornalístico Português anterior a 1974, tiveram acolhimento e eco em Informação, Cultura Popular e Turismo. Uma análise qualitativa de vários desses textos poderá comprovar se a hipótese é, de facto, passível de ser confirmada.

Dutra Faria (1970, p. 18-23) discorreu sobre as agências noticiosas oficiais e privadas. Destacou as últimas como devendo ser independentes, ao contrário do que sucede com as primeiras. No entanto, admite que, mesmo nas agências privadas é impossível assegurar que não haja determinadas influências, sejam estas exercidas por entidades como o Estado ou mesmo um cliente.

As agências noticiosas privadas são, por definição, independentes, ao contrário do que sucede com as agências noticiosas oficiais. É impossível evitar, porém, que sobre uma agência se não exerçam determinadas influências, que necessariamente estreitam a sua margem de independência: a do Estado (por meio da pressão fiscal e outras) ou a de um sector da sua clientela (por exemplo, o conjunto das associações industriais de um dado país) ou mesmo a de um só cliente, mas particularmente poderoso.

Na tentativa de caracterizar os jornalistas que trabalhavam para tais meios de informação, Faria (1970, p. 18-23) reconhece que entre esses profissionais e os que trabalhavam nas redacções dos jornais não havia grandes diferenças. Em ambos os casos, exigir-lhes isenção total era tarefa complicada de ver ser cumprida, pois uns e outros eram humanos.

Por outro lado, [...], os jornalistas que trabalham para as agências noticiosas são homens como os que trabalham nas redacções dos jornais ou como quaisquer outros homens. Vivem num determinado meio social e familiar, têm uma pátria e uma formação ideológica, as suas simpatias pessoais, os seus preconceitos, os seus tabus - e tudo isso conta - influi e pesa na redacção de uma notícia ou de uma crónica (e até no assestar de uma máquina fotográfica) por mais objectivo, por mais imparcial, por mais desapaixonado que se queira ser. Não se 
lhes pode exigir, pois, um grau tal de isenção que, se fosse possível, os desumanizaria, transformando-os em verdadeiros anjos... [...]

Afigura-se-me, assim, que é tão errado pensar que as agências de informação privadas são sistematicamente tendenciosas em relação a este ou àquele país, a este ou àquele Governo, a esta ou àquela política, como admitir ingenuamente que o jornalista ao serviço de uma agência pode ir no respeito pela ética da profissão até deixar de ser um homem como outro qualquer, com os seus defeitos, os seus prejuízos, as suas ideias preconcebidas...

Noutros aspectos da profissão, Faria (1970, p. 18-23) já identifica diferenças entre o jornalista que exerce a sua função numa redacção, com hora para entrar e sair, sentado confortavelmente a uma secretária e com jornais e livros ao lado, e um jornalista sem horários fixos, que anda de local em local em busca de informação para depois encontrar uma cabine telefónica e poder transmitir para a agência aquilo que descobriu.

Depois, e há ainda que não esquecê-lo, todo o jornalista, mas principalmente o correspondente de uma agência de informação, nada tem de comum com as pessoas que trabalham todos os dias úteis, das tantas às tantas (sempre as mesmas horas, com os mesmos intervalos, no mesmo período de tempo) e à noite, bem jantadas, vão tranquilamente ao cinema, ao teatro - ou ficam em casa, de pantufas, a ver Televisão: quando verdadeiramente dominado pela "paixão da notícia”, o correspondente ou o enviado especial da agência dorme quando pode - duas, três horas por noite, sempre que o trabalho aperta; come quando lhe é possível fazê-lo - quanta vez, como almoço ou como jantar, uma sanduíche ou um bolo, porque não há tempo para mais; mantém-se de pé e com os olhos abertos (abertos e atentos só à custa de cafés ou de álcool - e quanto mais frequentes ou mais graves forem os acontecimentos que o solicitem maior esforço ele exigirá de si próprio e dos seus nervos e mais facilmente, portanto, ele será traído pela sua excitação; que é a objectividade (sempre relativa, no entanto) e consegue-se sem excessiva dificuldade, quando estamos sentados confortavelmente a uma secretária, com os jornais ao lado e os nossos livros de consulta e os nossos "dossiers" de recortes de Imprensa ao alcance da mão, mas é difícil, tremendamente difícil, sei-o até por experiência própria, quando se telefona uma notícia de qualquer cabine pública, enquanto lá fora, na rua, de que apenas estamos separados por um vidro transparente, a "coisa" ainda está a suceder, como se a víssemos na pantalha do cinema. [...]

As diferenças entre os dois tipos de jornalistas continuam. Enquanto os jornalistas de redacção devem, essencialmente, saber escrever, os jornalistas de agência devem saber sintetizar; enquanto os primeiros conseguem controlar relativamente o tempo, os segundos correm contra o tempo. Dutra Faria (1970, p. 18-23) nota mesmo que os jornalistas que trabalhavam em agências eram, por vezes, apelidados de agenciários e que Portugal foi dos últimos países da Europa a ter uma agência nacional de informação internacional.

O jornalista de agência tem, por sinal, pouco de comum com o que trabalha na redacção de um jornal. Os franceses inventaram mesmo uma palavra para o definir - é o “agenciaire”, o agenciário.

O jornalista que trabalha na redacção de um jornal tem, é evidente, que saber escrever; mas o agenciário tem, sobretudo, que saber sintetizar.

$\mathrm{O}$ que trabalha na redacção de um jornal sabe que até à meia-noite (se o jornal é matutino) pode entregar a sua reportagem; mas para o agenciário não há intervalo entre a hora do acontecimento e a hora da sua transmissão - um segundo basta para que se chegue depois de uma agência concorrente.

Pode dar-se o jornalista propriamente dito ao luxo de "fazer estilo"; "condensar" [...] tem de ser um verbo presente sempre no espírito de cada agenciário. De resto, há também um estilo telegráfico e que não deixa de ter a sua beleza.

O jornalista pode antes de mais nada pensar em aprontar o seu trabalho e só depois preocupar-se com fazê-lo chegar à redacção; há sempre tempo. Mas o que não sabe já, antes de aprontar a notícia, como há-de transmiti-la à sua agência sem a mais pequena demora nunca será um autêntico agenciário.

O jornalista pode dizer que prefere aos outros meios de comunicação o telefone ou o telégrafo. Para o agenciário todos os meios de comunicação servem por igual, desde que rápidos. [...] Portugal foi dos últimos países da Europa a ter uma agência nacional de informação internacional.

Correia Marques (1970, p. 13-15 e 23-28), falando acerca da imprensa, assevera que esta, desde cedo, se assumiu como o quarto-poder. Reconhece que surgiu, essencialmente, com fins normativos e 
informativos, e relembra o início da imprensa periódica em Portugal.

A Imprensa diária e a Imprensa periódica começou por não existir [...]. Mas, nascida, bem depressa se tornou o "quarto-poder". [...]

A Imprensa nasceu especialmente com fins normativos e informativos. [...]

No nosso país a imprensa periódica teve começos animados de alto patriotismo. Nasceu pouco depois da Restauração, para dar notícias da guerra nem sempre feliz, e da política também por vezes malsinada por inimigos internos e externos. Era necessário dar dos acontecimentos castrenses e da marcha diplomática, informação conveniente para animar os espíritos em Portugal, inspirando-lhes confiança, e para contrabater a aç̧ão diplomática da Espanha preponderante no mundo de então. [...]

A imprensa moderna também tem lugar nas reflexões de Marques (1970, p. 13-15 e 23-28). O autor afirma que esta era, na época, mais moderada e tinha um carácter meramente informativo, comparativamente aos séculos anteriores. O autor reconhece, porém, que essa informação assumia, por vezes, aspectos tendenciosos e era, até, copiosa.

Hoje a Imprensa tem uma feição muito mais moderada que há meio século. Todavia tempo levou que atingisse esta moderação e compostura. [...].

Mas hoje é outro o panorama geral da Imprensa portuguesa. Como em quase todo o mundo, tomou um carácter especialmente informativo. Mas desta Imprensa moderna se pode dizer aquilo do romancista suíço Eduardo Rod: "Depois que os jornais publicam tantas notícias já a gente não sabe o que se passa." Com efeito, é difícil, nos dias de hoje, orientar-se o leitor na selva emaranhada da informação, tão copiosa e em geral tendenciosa. Porque a Imprensa é um enorme poder para transviar os espíritos, mesmo que dê só notícias. Muito vai na maneira de as dar: título, tipo escolhido, colocação em página, valem bem pelos comentários ausentes. $[\ldots]$

A imprensa formativa, que, a bem da verdade, procura comentar acontecimentos e ideias, também merece alguns reparos do autor (1970, p. 13-15 e 2328). Após explicar as fracas tiragens dos jornais católicos e políticos do seu tempo, Marques reconhece que, no fundo, a imprensa era uma arma, tanto para o bem como para o mal.
A Imprensa formativa não se dispensa, de em serviço à verdade, comentar os acontecimentos e as ideias. Para isso tem os seus editorialistas e os seus colaboradores. Todos os jornais diários são simultaneamente informativos e políticos. Há, porém, uma imprensa que tem como tema principal doutrinas religiosas ou políticas. [...] Portugal é considerado país católico e nos inquéritos das estatísticas 95\% dos portugueses se declaram católicos. Mas a tiragem dos jornais católicos é sempre muito menor que a da imprensa neutra em assuntos religiosos. Por quê? Porque os católicos se desinteressam da defesa das suas ideias pelo meio da letra diariamente impressa. Por isso procuram mais facilmente e insistentemente os jornais neutros. E daí resulta terem os jornais católicos menor tiragem, menos cópia de publicidade, e, portanto, menos páginas, menos que ler, com que entreter o espírito. [...] O mesmo acontece com a Imprensa estritamente política. A sua tiragem (falo do nosso país) é habitualmente reduzida.

Nos tempos modernos a Imprensa é uma arma poderosa para o bem e para o mal. [...]

Marques (1970, p. 13-15 e 23-28) estabelece, também, uma comparação entre a imprensa e os seus competidores: o cinema e a rádio e a televisão. Os dois últimos meios são considerados mais ameaçadores, uma vez que podem dar a notícia no momento em que ela surge ou acontece.

A Imprensa encontrou, no nosso tempo, competidores na expansão e influência: o cinema com as suas "actualidades" foi o primeiro competidor, mas pouco de temer, pois só tarde e muito reduzidamente pode dar notícia dos factos; mas a rádio e a televisão são mais de recear porque dão as notícias no momento em que elas surgem. E a televisão além de notícia falada dá a notícia pela imagem. [...] Não há dúvida que especialmente os progressos da TV virão a prejudicar a Imprensa. Mas o perigo é ainda limitado. Por enquanto a vítima da TV é o cinema. É ver como rapidamente a TV se multiplica e populariza: em muitas cidades, vilas e até aldeias de Portugal os comerciantes a instalam para fruição dos fregueses.

E todas as noites têm casa cheia. Compreende-se: pelo preço de um café por cabeça, um escudo por cabeça - tem uma família inteira algumas horas de espectáculo. Os bilhetes de cinema vão de $15 \$ 00$ a $20 \$ 00$ por pessoa. As casas de espectáculo cinematográfico em Lisboa e Porto sentiram logo os efeitos desta concorrência. [...] 
Inimigo da Imprensa, dizem os jornalistas, é o cinema. Sem dúvida a censura é molesta e impede aos jornais um poder tão português de dizer mal do Governo, mesmo que não haja razão. [...]

Os últimos reparos do autor são feitos à censura prévia e à sua actuação no campo da imprensa. O autor comenta, ainda, que "esta medida repressiva existirá sempre”, na forma de exame prévio ou noutra qualquer (MARQUES, 1970, p. 13-15 e 23-28).

A censura prévia às publicações impressas antes de serem impressas ou entregues ao público foi pela primeira vez implantada em Portugal pelo Tribunal do Santo Ofício, estabelecido em 1536. A censura inquisitorial ou exame prévio aos livros data de 1539. [...] Mas a censura prévia, que ora nos interessa, é a que se aplica à Imprensa periódica. Deve dizer-se que ela nasceu com a Imprensa, porque [...] a "gazeta em que se relatam as novas todas..." foi suspensa em 19 de Agosto de 1642, por ser pouco verdadeira e mal escrita.

A censura existiu no decorrer dos tempos de vez em quando. Hoje encontra-se regulada pelo Decreto n. ${ }^{\circ} 22$ 469, de 11 de Abril de 1933. [...] Em boa verdade, desde que o jornalista não seja dono do jornal tem sempre uma censura, a da direç̧ão do periódico. E o próprio director, se é apenas um funcionário mais categorizado da redacção, dos interesses da Imprensa para que trabalha, depende quanto ao critério de expor e comentar certos factos. [...]

Costuma dizer-se que a censura impede os talentos de se manifestarem. De se manifestarem contra o regime vigente, contra os seus princípios fundamentais, contra a ordem social, contra a moral nacional - sim: mas não são estas, forçosamente, as formas de se manifestar o talento. A censura não impede que se escreva bem e com talento e brilho o que é permitido escrever. [...]

Sendo assim como se entende que o autor deste artigo por vezes se haja mostrado contrário à censura? Porque ela o molesta e também porque preferia escrever o que lhe desse na pessoalíssima gana - o que nunca sucederia porque nunca foi, nem será dono de um jornal.

E assim será sempre, de qualquer forma, de suportar alguma espécie de censura.

José Lechner (1971, p. 9-17) foi outro dos autores que contribuiu para a revista Informação, Cultura Popular e Turismo. Num texto intitulado "O Boato” discorreu sobre as relações entre o estado da opinião pública de um país e a informação que se transmite. Da última depende o bom estado da primeira, diz o autor. Se a informação que corre é apenas um "boato”, a opinião pública vai-se formar com algumas debilitações.

O estado de saúde de uma opinião pública, quer nacional quer internacional, é tributário quase que exclusivamente do funcionamento da informação. As perturbações desta afectam aquela, directa, imediata e inevitavelmente.

Nos países que sofrem de uma subinformação crónica, e para mais adulterada, criam-se canais de informação "informais", essencialmente orais, que veiculam informações incontroláveis: os chamados "boatos" ou "rumores".

Mas não basta verificar que o "boato" é sintoma das carências ou deficiências da informação colectiva. É preciso dizer também, e logo, que o boato é sobretudo um elemento patogénico, susceptível de provocar na opinião pública verdadeiras epidemias emocionais que se podem traduzir, conforme as circunstâncias, em ansiedade, agressividade, pânico, ou, nalguns casos, em alegria e esperança igualmente doentias. [...]

O autor procura, também, expor as características gerais do boato (a sua formação, a sua propagação, as suas funções). Explica ele que o boato é, genericamente, uma notícia anónima que circula livremente, “de boca em boca”, sem se saber de onde vem e para onde vai e interessando a toda a gente. E distingue duas categorias de características de boatos: as que dizem respeito ao seu processo de formação e as que explicam os mecanismos da sua propagação (LECHNER, 1971, p. 9-17). Em relação ao processo de formação, diz o autor que este surge em função de um "potencial de difusão e de uma intensidade de estimulação, ambos referentes a uma população determinada, numa unidade de tempo dada, numa certa altura histórica e num lugar conhecido". (LECHNER, 1971, p. 9-17). Esse potencial de difusão define-se como "o número de pessoas atingidas por um boato durante uma unidade de tempo considerada". O autor afirma que a receptividade das pessoas aos boatos aumenta "na razão directa da falta de informações precisas, exactas e rápidas, sobretudo em circunstâncias graves criadas por acontecimentos ameaçadores como guerras, revoluções, crises económicas e políticas ou catástrofes naturais." (LECHNER, 1971, p. 9-17). Relativamente ao 
segundo factor de formação de um boato, a intensidade de estímulo, esta se mede "pela quantidade inicial de mensagem idêntica injectada na população considerada, assim como pelo seu conteúdo", caso sejam boatos provocados (LECHNER, 1971, p. 9-17).

No que aos mecanismos de propagação diz respeito, Lechner (1971, p. 9-17) afirma que esta se efectua "seguindo a estrutura das relações afectivas existentes num grupo, e que a transmissão de indivíduo para indivíduo altera a mensagem em conformidade justamente com os sentimentos predominantes no grupo”. Identifica, ainda, três leis de transformação:

- simplificação progressiva, ou nivelamento, o que quer dizer que os pormenores da história contida no boato se perdem a cada repetição. Uma manifestação que mobilizou milhares de pessoas e levou um dia a realizar-se, conta-se em cinco minutos;

- amplificação progressiva, que se traduz por uma acentuação de certos aspectos que tomam uma posição reforçada na história. Uma pessoa ferida durante a manifestação será morta no boato, os mortos multiplicar-se-ão e no fim falar-se-á de execuções em massa;

- assimilação, que significa que a mensagem recebida é reestruturada pelo receptor em função dos seus centros de interesse. Reformulando subjectivamente a história, o receptor confere um sentido e uma coloração particular ao boato. Assim, mesmo alterado, o boato tem sempre uma coerência lógica interna, sem a qual seria incomunicável.

Ee seguida, Lechner (1971, p. 9-17) tenta explicar para que servem os boatos e por que razão existem. Assim, o autor declara que os boatos servem, simultaneamente, para explicar situações ambíguas e aliviar a tensão. Considera, também, que, por mais falso que um boato seja, contém sempre alguma informação, apesar de este, com as sucessivas transmissões, ir perdendo a verdade factual que, inicialmente, possa deter (LECHNER, 1971, p. 9-17). Para Lechner (1971, p. 9-17), o boato quase pode ser considerado uma arma de propaganda.

O fenómeno boato esclarece-se mais ainda à luz da análise das suas funções psico-sociais: para que servem os boatos? Quais são as suas razões de ser? Excluindo os boatos sem grande significação social (bisbilhotices e as conversas de lazer) e considerando apenas os boatos que exprimem atitudes latentes e estados afectivo-emocionais de carácter colectivo, chega-se a uma tipologia funcional muito reveladora. De uma maneira geral, os boatos servem simultaneamente para explicar situações ambíguas e aliviar a tensão, reduzindo as incertezas perante os perigos. [...]

[...] o boato preenche funções semelhantes às das opiniões, crenças, mitos e fábulas sem se confundir com estes [...].

O boato é, portanto, uma informação intrinsecamente efabuladora justamente porque nasce como sucedâneo do conhecimento objectivo e controlável. Por outras palavras, mesmo quando um boato contém, inicialmente, uma verdade factual, o seu conteúdo não pode ser confirmado pelos sucessivos receptores e sofre, por isso mesmo, durante a sua transmissão, transformações tais, que o seu fundo de verdade desaparece. Pior ainda: o boato, por mais falso que seja, não deixa de ser informação, e como tal, vai afectar o comportamento dos receptores. [...]

Em resumo, a análise funcional do boato mostra que este é produto, simultaneamente, da necessidade imperiosa e da carência manifesta de informações completas. É um produto patogénico não só porque resulta de uma doença da informação, mas sobretudo porque, posto em circulação, contamina a opinião pública. Pode estar na origem de preconceitos e estereótipos; pode criar correntes de opiniões hostis, agressivas ou aterrorizadas e pode alterar opiniões ou crenças já estabelecidas. A sua virulência, particularmente no caso dos boatos caluniosos, pode causar delírios colectivos [...]. As perseguições raciais, os conflitos religiosos e ideológicos abundam em atrocidades originadas por boatos caluniosos. O boato toma assim lugar, naturalmente, no arsenal das armas da propaganda.

Ao chegar à última parte do seu artigo, Lechner (1971, p. 9-17) fornece algumas indicações de como se pode criar um mecanismo de defesa contra os boatos. Aponta a prevenção como a melhor solução, passando esta pela observação da forma de circular da informação. É nessa ocasião que se pode evitar que o boato se forme e vá circulando.

A melhor defesa é, sem dúvida, a prevenção dos boatos pela observância das regras mais elementares da higiene da opinião pública, a saber: a livre circulação das informações nacionais e internacionais através dos meios colectivos de informação e a prática regular e sistemática da informação oficial de forma a criar um clima de confiança entre o público e os serviços da Administração pública. 
Quando a Administração pública está apetrechada com um sistema de informação funcional para recolha, tratamento e transmissão de inúmeras informações [...], a prevenção dos boatos é possível mesmo em situações de emergência como, por exemplo, um abalo sísmico, uma epidemia ou inundações catastróficas. Basta informar o público com rapidez e sem ambiguidade para lhe permitir tomar decisões oportunas em tempo útil antes mesmo que a insegurança gere, quase que automaticamente, a irrupção de boatos.

Ao terminar, Lechner (1971, p. 9-17) lembra que as medidas preventivas podem não ser suficientes para impedir um boato de nascer, crescer e se reproduzir, daí que aconselhe, também, uma defesa defensiva, que passe pela detecção, análise e destruição do boato, assim que este surja.

Evidentemente, as medidas preventivas não são suficientes. A defesa antiboato deve ser também uma defesa ofensiva, quer dizer: uma operação de detecção, de análise e de destruição dos boatos em circulação.

A detecção é relativamente fácil na maioria dos casos. O observador-caçador de boato que ouve só uma vez uma informação oral socialmente significativa, materialmente incontrolável e susceptível de provocar efeitos graves, pode e deve providenciar tão rapidamente quanto possível, para difundir informações oficiais controláveis que provem o contrário das afirmações contidas no boato, e tomar, ao mesmo tempo, medidas capazes de neutralizar os efeitos possíveis do boato. [...] A detecção é mais difícil, nomeadamente para os jornalistas, quando o boato tem como origem as "confidências" oficiosas, as "fugas" simuladas, os "balões de ensaio" e as "indiscrições disfarçadas" dos meios políticos que querem "tomar a temperatura” do público (começando pelos próprios jornalistas) através da sua reacção à pseudo-notícia. Os jornais sensacionalistas, sempre atentos a uma boa "caixa”, caem na armadilha. Os jornalistas dignos desse nome não publicam notícias incontroláveis ou apresentam-nas como tais, conforme o princípio de que "vale mais ser o segundo a publicar uma notícia verídica do que ser o primeiro a publicar uma notícia falsa”. [...] O resultado da análise [de conteúdo] deve mostrar se o boato é ou não capaz de se consolidar numa conjuntura dada e quais são as medidas mais pertinentes e válidas para destruir os seus efeitos. [...] Na prática, a ofensiva antiboato pela utilização de contraboatos obedece a quatro regras simples:
- dividir a área considerada (uma cidade, uma região, um país) em zonas de difusão e calcular a intensidade do estímulo em função da densidade da população;

- escolher os agentes de propagação segundo dois critérios sociométricos: a) pessoas que têm muitos contactos directos com o maior número possível de indivíduos (cabeleireiros, médicos, dentistas, sacerdotes, porteiros, motoristas de táxi, empregados de café e de restaurante, etc.); b) pessoas que são "leaders" de opinião no seu sector;

- elaborar uma mensagem tão concisa quanto for necessário para ser mecanicamente memorizável; - a injecção deve ser simultânea em várias zonas de difusão e efectivar-se tão confidencialmente ou incidentalmente quanto possível.

José Marques de Melo, por sua vez, abordou o tema dos periódicos semanais ilustrados. O autor começa por lamentar a falta de investigação sobre a imprensa não diária, nomeadamente nos países iberoamericanos, e a tendência das escolas de jornalismo desses países de formarem, essencialmente, profissionais para trabalharem na imprensa diária, relegando para segundo plano qualquer outro tipo de publicações (MARQUES DE MELO, 1973, p. 4764). Por esse motivo, o autor propõe-se investigar o estado do jornalismo semanal ilustrado, uma forma de publicação não diária, tendo como objectivo principal comparar o jornalismo semanal ilustrado de vários países, através da análise de quatro revistas (Paris Match - França; L'Éuropeo - Itália; Stern - Alemanha; Life - Estados Unidos), tendo como ponto de referência a realidade brasileira e a revista Manchete (MARQUES DE MELO, 1973, p. 47-64).

Los estudios de Periodismo Comparado se orientan, generalmente, hacia el campo de los diarios. Se comprende, hasta cierto punto, tal tendencia, dada la significación social que posee el periodismo diario en la situación actual de desarrollo de la sociedad industrial. Lo que no se justifica es la casi ausencia de investigaciones sobre el periodismo no-cotidiano, sobre todo en las entidades universitarias. Quizá ese fenómeno constituya el reflejo de una orientación pedagógica tradicionalista en el área instrumental (con énfasis en los países iberoamericanos), pues las Escuelas de Periodismo siguen formando profesionales volcados técnicamente hacia las actividades de los periódicos diarios, ignorando las revistas, y, por tanto, los profundos cambios de las informaciones 
de actualidad en esta fase de "exposición de las comunicaciones". [...]

Esta investigación - que abarca especialmente al periodismo semanal ilustrado - representa así una toma de posición frente a ese panorama y tiene la intención de contribuir a la sistematización de una metodología adecuada al estudio de los vehículos impresos no-diarios.

El objetivo principal de este trabajo es el de comparar el periodismo semanal ilustrado de varios países, tomando como punto de referencia la realidad brasileña. Por esto se hizo una selección a cuatro revistas extranjeras: tres europeas Paris Match (francesa), L'Europeo (italiana), Stern (alemana) - e una norte americana (Life), para campararias con una revista del Brasil cuya preferencia recayó sobre Manchete. [...]

Marques de Melo (1973, p. 47-64) explica que a revista ilustrada, como meio de comunicação colectivo, abarcava três categorias de mensagens - a própria informação jornalística, a publicidade e o entretenimento - estando essa divisão relacionada com as funções básicas dos meios de comunicação de difusão colectiva: informação, persuasão e passatempo. Nas revistas que o autor analisou, as matérias de informação jornalística ocupam mais de dois terços do espaço. Por sua vez, o entretenimento é a categoria que ocupa menos extensão nas revistas analisadas. A publicidade, que ocupa um espaço razoável, varia no que diz respeito à localização, conclui o autor.

Outra conclusão a que o autor chegou mostra que os assuntos sobre política, religião e problemas sociais são os que conseguem um lugar mais destacado e com maior número de páginas nas revistas investigadas. Os chamados assuntos femininos (família, crianças, moda e culinária) também ocupam um espaço considerável nessas publicações. Uma das revistas afasta-se da tendência geral e dedica mais espaço a assuntos relacionados com os meios de comunicação colectiva (MARQUES DE MELO, 1973, p. 47-64).

La tendencia dominante en el conjunto de las revistas estudiadas es la de atribuir lugar destacado a los asuntos política, religión, problemas sociales. A primera vista, tal comprobación desvinculada de un contexto más general, podría determinar a las revistas semanales ilustradas una orientación "masculina”, con vistas principalmente a un público de ese género. Sin embargo, esa impresión ini- cial (válida por la incidencia cuantitativa) se neutraliza cuando observamos la presencia de asuntos "femeninos", lo que muestra una orientación masculina-femenina.

Relativamente à inserção de imagens nessas revistas, Marques de Melo (1973, p. 47-64) conclui que o homem é aquele que surge em mais imagens e fotografias, ocupando mais de 50\% do espaço, em todas as publicações analisadas. Esse homem é normalmente um ser famoso, uma personalidade. Mas também há imagens de homens anónimos. Essa inserção de "vedetas” e “desconhecidos” permite, nas palavras do autor, uma interacção entre o real e o irreal.

Na última parte da sua investigação, Marques de Melo (1973, p. 47-64) falou da parte gráfica das revistas, informando que, por norma, todas elas obedeciam à estrutura habitual de apresentar texto, ilustrações/imagens e espaço em branco (onde se inserem os títulos). Nas cinco revistas analisadas por Melo, a composição gráfica é bastante homogénea com as ilustrações a surgirem de forma maioritária. As fotografias constituem a maior parte das imagens, enquanto que os desenhos e os gráficos têm uma presença diminuta. Todas elas podem ser coloridas ou a preto e branco.

Na revista Informação, Cultura Popular e Turismo, do Gabinete Técnico da Secretaria de Estado da Informação e Turismo, foram ainda publicados outros textos que tinham como tema central o jornalismo, mas não foram escritos por jornalistas. Em conjunto com os textos analisados neste trabalho, constituem uma amostra daquilo que certos indivíduos - de alguma forma relacionados com o mundo da comunicação e, em particular, com o mundo do jornalismo - pensaram sobre esse mundo, sobre as suas transformações e sobre o seu futuro. Reflectiram sobre alguns aspectos da profissão de jornalista, sobre os meios de comunicação, em geral, sobre outros, em particular, e sobre todo um conjunto de temas jornalísticos que haviam vivido, até ao momento, de certa forma, sem qualquer tipo de estudo ou investigação. Daí a importância que os diversos artigos sobre jornalismo publicados em Informação, Cultura Popular e Turismo tiveram - quer no sentido de dar oportunidade de se analisarem e investigarem, com algum grau de cientificidade, esses assuntos - e 
têm, uma vez que ao estudar o passado estamos a compreender melhor o presente.

\section{Considerações finais}

Lendo-se e/ou relendo-se os textos sobre jornalismo, escritos por jornalistas e publicados na revista Informação, Cultura Popular e Turismo, do Gabinete Técnico da Secretaria de Estado da Informação e Turismo, que veio a lume entre 1970 e 1973, percebe-se que os principais temas acerca dos quais versavam esses artigos eram: a Informação e a sua importância na década de setenta, bem como o modo como esta era transmitida, por quem, e a quem se destinava; os meios de comunicação social ou meios de comunicação de massas, a sua evolução e a sua utilidade, suas vantagens e desvantagens; o modo como a sociedade, que se encontrava em mudança, se interligava com esses meios; as transformações ocorridas no panorama jornalístico, essencialmente na década de setenta; a opinião pública, sua formação e sua relevância; o jornalismo e os jornalistas no período do marcelismo, em Portugal e além-fronteiras.

Assim, como primeira consideração final, pode afirmar-se que os jornalistas que colaboraram na revista com a publicação de artigos cuja temática geral era o jornalismo, preocuparam-se em reflectir sobre os meios de comunicação social, com especial destaque para aqueles que tinham mais impacto e público, a imprensa e a rádio, mas sem esquecer os que emergiam, como a televisão, ou os que, para alguns, se afastavam um pouco do mundo jornalístico, como é o caso do cinema. Percebe-se o papel importante que esses meios de comunicação desempenhavam na formação da opinião pública e, também, que se considerava que eles influenciavam comportamentos, atitudes e hábitos. As transformações e mudanças que nesse campo se verificavam também motivavam o debate.

Tendo Informação, Cultura Popular e Turismo em consideração, é correcto afirmar-se que a história do jornalismo esteve, constantemente, presente no discorro dos autores que escreveram sobre assuntos do foro da Informação. A história dos diferentes meios de comunicação social, como já se referiu, foi abordada, e o seu futuro foi discutido, como prova da preocupação que motivavam naqueles que reflectiam sobre o jornalismo. Na revista discorreu-se, ainda, sobre os jornalistas, a sua história e o seu valor na sociedade de então, procurando elevar-se e dignificar-se a profissão, que tinha enorme contribuição na comunicação entre os seres humanos e que ajudava a que estes se mantivessem informados e que pudessem informar. E, embora sendo a revista propriedade de um organismo estatal, por uma ou outra vez questionou-se a censura contra a imprensa e a actuação da censura prévia, e clamou-se pela liberdade de expressão de pensamento e de opinião.

É possível, também, compreender que o discurso adoptado pelo Gabinete Técnico da Secretaria de Estado da Informação e Turismo, nomeadamente na revista em análise, é predominantemente informativo e moderado, com pretensão de esclarecimento, justificação e, porventura, orientação.

No que respeita à contribuição da revista Informação, Cultura Popular e Turismo, para a construção do Pensamento Jornalístico Português, pode dizer-se que os seus redactores, nos textos que escreveram sobre jornalismo, se preocuparam em dar respostas a algumas questões que ainda se colocavam relativamente à conceptualização da profissão, tais como: de onde surgiu o jornalismo e como é que a história o conduziu aos dias de hoje (anos setenta)? O que se deve fazer para melhor compreender a profissão jornalista? Quais os meios de que se dispõe para fazer circular a Informação e como é que os jornalistas os devem usar? Qual o caminho a percorrer de modo que o jornalismo e os jornalistas acompanhem as transformações que ocorrem na sociedade? As respostas ou as explicações a essas e outras questões relevantes para o imaginário e para a identidade profissionais nem sempre foram concordes, mas foram, normalmente, pertinentes. Sobretudo, elas dão uma panorâmica do que se pensava, nos primeiros anos da década de setenta do século XX, sobre a profissão jornalista e sobre o jornalismo. Portanto, como última consideração final, é possível aceitar a hipótese colocada na introdução, pois Informação, Cultura Popular e Turismo abordou e discutiu aqueles que, de acordo com Sousa (2010), são os temas estruturantes do Pensamento Jornalístico Português anterior a 1974: conjuntura jornalística e vida profissional; história do jornalismo; e teoria do jornalismo em geral. 


\section{Referências}

CABRERA, Ana. Marcelo Caetano: o poder e a imprensa. Lisboa: Livros Horizonte, 2006.

CABRERA, Ana. Os jornalistas no Marcelismo: dinâmicas sociais e reivindicativas. In: TRAQUINA, Nelson (Org.). Do chumbo à era digital: 13 leituras do jornalismo em Portugal. Lisboa: Livros Horizonte, 2010. p. 71-84.

CORREIA, Fernando; BAPTISTA, Carla. Anos 60: um período de viragem no jornalismo português. In: TRAQUINA, Nelson (Org.). Do chumbo à era digital: 13 leituras do jornalismo em Portugal. Lisboa: Livros Horizonte, 2010. p. 53-70.

CORREIA, Fernando; BAPTISTA, Carla. Jornalistas: do ofício à profissão: mudanças no jornalismo português (19561968). Lisboa: Caminho, 2007.

FARIA, Dutra. Agências de informação. Informação, Cultura Popular e Turismo, Lisboa, n.1, p. 18-23, 1970.

FRANCO, Graça. A censura à imprensa (1820-1974). Lisboa: IN-CM, 1993.

LECHNER, José. O boato. Informação, Cultura Popular e Turismo, n. 5, p. 9-17, 1971.

MARQUES, Correia. A imprensa diária. Informação, Cultura Popular e Turismo, n. 3, p. 13-15 e 23-28, 1970.

MARQUES DE MELO, José. Periodismo semanal ilustrado. Informação, Cultura Popular e Turismo, n.13, p. 47-64, 1973.

RAMOS, Rui (Coord.); SOUSA, Bernardo Vasconcelos; MONTEIRO, Nuno Gonçalo. História de Portugal. Lisboa: A Esfera dos Livros, 2009.

ROSAS, Fernando. O Estado Novo (1926-1974). In: MATTOSO, José. História de Portugal. Sétimo volume. Lisboa: Círculo de Leitores, 1994.

SOBREIRA, Rosa Maria. O ensino do jornalismo e a profissionalização dos jornalistas em Portugal (1933-1974). In: TRAQUINA, Nelson (Org.). Do chumbo à era digital: 13 Leituras do jornalismo em Portugal. Lisboa: Livros Horizonte, 2010. p. 17-36.

SOBREIRA, Rosa Maria. Os jornalistas portugueses 1933-1974: uma profissão em construção. Lisboa: Livros Horizonte, 2003.

SOUSA, Jorge Pedro. Elementos de teoria e pesquisa da comunicação e dos media. 2.ed.rev. e amp. Porto: Edições Universidade Fernando Pessoa, 2006.

SOUSA, Jorge Pedro. Uma história do jornalismo em Portugal até 25 de Abril de 1974. In: SOUSA, Jorge Pedro (Org.). Jornalismo: história, teoria e metodologia da pesquisa. Porto: Edições Universidade Fernando Pessoa, 2008. p. 93-118.
SOUSA, Jorge Pedro (Coord.) et al. O pensamento jornalístico português: das origens a abril de 1974. 2 volumes. Covilhã: Livros LabCom, 2010.

Recebido em: 12 de setembro de 2011 Aceito em: 14 de abril de 2012 